Article

\title{
Updating the Florida Keys National Marine Sanctuary Management Plan: Estimating the Impact to Commercial Fishing in Monroe County, Florida
}

\author{
Danielle Schwarzmann ${ }^{1, *}$, Amy Freitag ${ }^{2}$, Dan Dorfman ${ }^{3}$, David Records 4 (D) and Meredith Walz ${ }^{1}$ \\ 1 NOAA's Office of National Marine Sanctuaries, 1305 East West Hwy, Silver Spring, MD 20910, USA; \\ meredith.walz@noaa.gov \\ 2 NOAA's National Center for Coastal and Ocean Science, 1305 East West Hwy, Silver Spring, MD 20910, USA; \\ amy.freitag@noaa.gov \\ 3 CSS Inc., 2750 Prosperity Ave Suite 220, Fairfax, VA 22031, USA; dan.dorfman@noaa.gov \\ 4 National Marine Fisheries Service, Southeast Regional Office, 263 13th Avenue S, \\ St. Petersburg, FL 33701, USA; david.records@noaa.gov \\ * Correspondence: danielle.schwarzmann@noaa.gov
}

\section{check for} updates

Citation: Schwarzmann, D.; Freitag A.; Dorfman, D.; Records, D.; Walz, M. Updating the Florida Keys National Marine Sanctuary Management Plan: Estimating the Impact to Commercial Fishing in Monroe County, Florida. Water 2022, 14, 290. https://doi.org/10.3390/ w14030290

Academic Editor: José Luis Sánchez-Lizaso

Received: 9 November 2021 Accepted: 5 January 2022

Published: 19 January 2022

Publisher's Note: MDPI stays neutral with regard to jurisdictional claims in published maps and institutional affiliations.

Copyright: () 2022 by the authors Licensee MDPI, Basel, Switzerland. This article is an open access article distributed under the terms and conditions of the Creative Commons Attribution (CC BY) license (https:// creativecommons.org/licenses/by/ $4.0 /)$.

\begin{abstract}
This article is designed to provide the methodologies used to estimate the impact to the commercial fishing industry as a result of spatial zone management changes within Florida Keys National Marine Sanctuary and its study area, Monroe County, FL. The analysis provided here provides a template for how to estimate economic impacts when refined human use spatial data are not available. Utilizing existing habitat maps and economic data, this method downscales traditional economic methods using a spatial approach to match the fine-scale management approach utilized by the National Marine Sanctuary System. This approach allows the authors to estimate the economic impacts to the commercial fishing sector. The authors find that the proposed spatial zone changes may result in an estimated loss of 42 jobs, with 28 being harvester jobs, to the state of Florida. Additionally, \$4.1 million in output and approximately $\$ 1.1$ million in income may be lost. These estimates do not take into account the likelihood of substitution to alternative fishing grounds or adjusting the target species.
\end{abstract}

Keywords: commercial fishing; Florida; Florida Keys National Marine Sanctuary; economic impacts

\section{Introduction}

The National Oceanic and Atmospheric Administration's (NOAA's) Office of National Marine Sanctuaries (ONMS) serves as the trustee for a network of underwater parks encompassing more than 600,000 square miles of marine and Great Lakes waters. Within the system, there are fourteen national marine sanctuaries and Papahānaumokuākea and Rose Atoll marine national monuments. The National Marine Sanctuary System (NMSS) protects America's most iconic natural and cultural marine resources and works with diverse partners and stakeholders to promote responsible, sustainable ocean uses that ensure the sustained health of America's most valued ocean places. Healthy sanctuaries and a healthy ocean provide multiple ecosystem services including recreation and commercial activities that support coastal economies [1].

Designated 16 November 1990 by Congress, Florida Keys National Marine Sanctuary (FKNMS) encompasses 3800 square miles of ocean. The sanctuary surrounds more than 1700 islands, spanning the shallow water interface between the Gulf of Mexico and the Atlantic Ocean. Within this area, the sanctuary protects open ocean, offshore reef tract and nearshore patch reefs, seagrass meadows, hard bottom regions, and fringing mangroves, supporting both tropical and subtropical species diversity. Within sanctuary boundaries is the largest documented contiguous seagrass community in the Northern Hemisphere, extensive coral reef habitat and maritime heritage resources [2]. 
Both cultural and natural resources provide a variety of ecosystem services to the residents and visitors of the Florida Keys. Monroe County, Florida is home to FKNMS and is the entrance to Dry Tortugas National Park in the south and provides access to portions of the Everglades and Biscayne Bay National Parks (Figure 1). Further, there are several state parks in the region. For the purposes of economic analysis, Monroe County is considered the local study area to Florida Keys National Marine Sanctuary. In 2018, tourism spending in Monroe County was estimated at $\$ 2.4$ billion and supported $44 \%$ of jobs/employment in the county [3]. Without this tourism, the 30,200 households in Monroe County would need to pay an additional \$3750 in local taxes annually to maintain current levels of tax revenue.

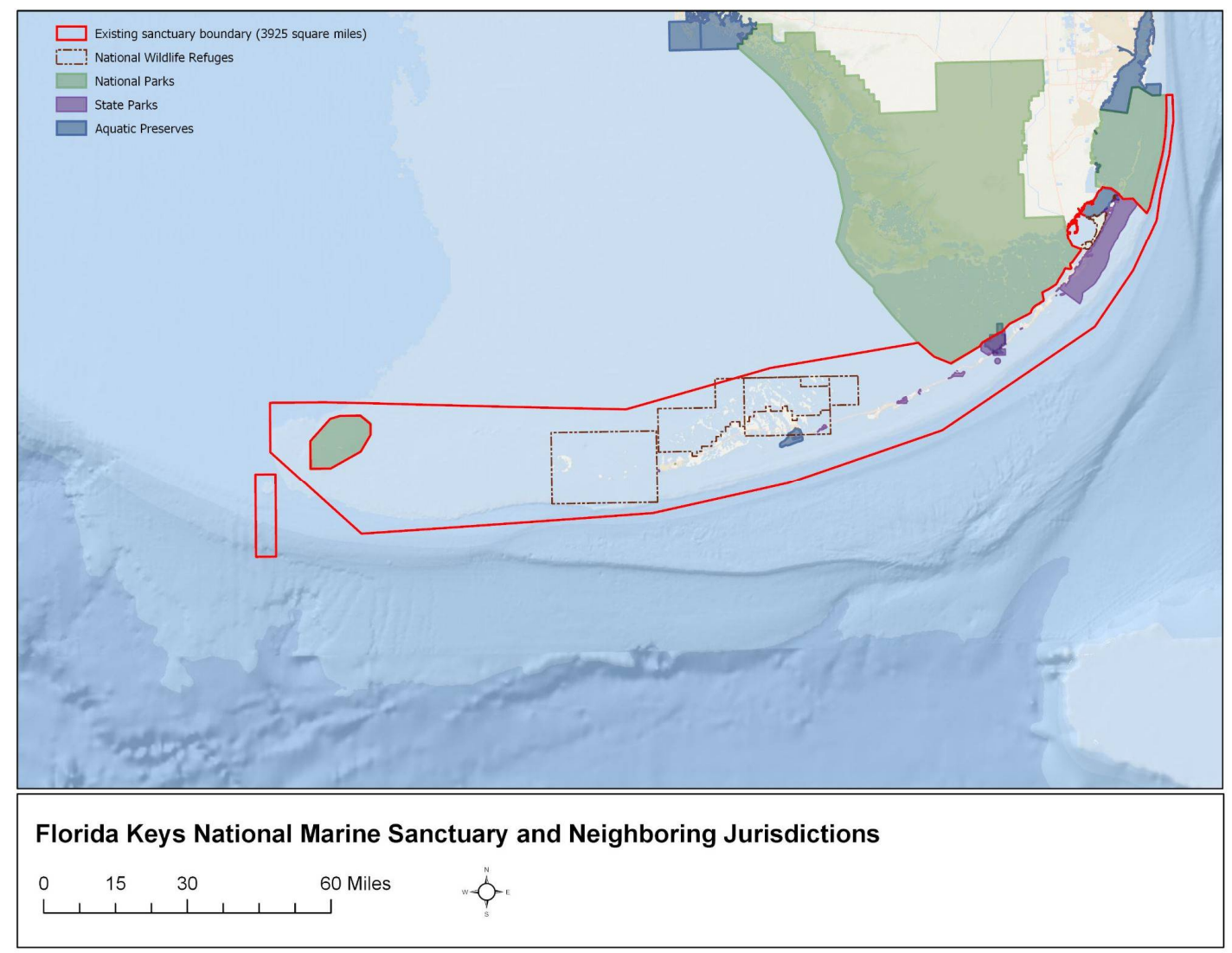

Figure 1. Overview of the FKNMS boundary and neighborhood conservation jurisdictions.

The goal of this article is to present the process and methods used to analyze the impact of proposed spatial zone changes to improve conservation management and stewardship of ecologically sensitive areas in Florida Keys National Marine Sanctuary. Within the United States, there are seven regional fishery management councils. When fishery regulations are implemented, they most often apply to the region and align with the scale of existing data collection efforts. However, when managing smaller marine zones, regulations may affect fisheries differently. Existing data collection efforts on use and effort do not allow for the direct analysis of impacts to these smaller marine protected areas, and alternative methods are needed to estimate the impacts of such regulations. This paper will detail a process to analyze the impacts of smaller marine zones when the relevant economic fishery and effort data are not available at the needed spatial scale. The data sets and methods needed to successfully analyze economic impacts will be explained so that others may apply this method in similar situations. 


\subsection{Ecosystem Structure}

The Florida Keys reef tract is composed of several different coral habitat types that run parallel to the dominant water flow from the Florida Current. Heading offshore from the islands, one first encounters inshore patch reefs followed by mid-channel then offshore patch reefs, and finally high-relief fore reefs [4]. These tropical reef communities are known for their high biodiversity by providing essential juvenile nursery habitat, foraging grounds, and sheltering grounds; as a result, many are included within special management zones [5].

In addition to hosting the longest continuous reef tract of North America, the ecosystem includes several species of corals listed as threatened under the Endangered Species Act (for example, the elkhorn and staghorn corals that are the focus of current restoration efforts), important spawning aggregations for key fish species, reef areas identified as resilient to disease and bleaching, seagrass meadows, mangrove habitats, and remote high-relief reefs.

\subsection{Ecosystem Services}

We define ecosystem services as the benefits people obtain from natural and cultural resources through use, consumption, enjoyment and/or simply knowing these resources exist. Marine sanctuaries periodically produce scientific reports on the status and trends of sanctuary resources and ecosystem services in consultation with subject matter experts. In these "condition reports," the status and trends of selected final ecosystem services are evaluated for each marine sanctuary.

FKNMS offers many final ecosystem services to residents and visitors, including cultural (non-material benefits, such as non-consumptive recreation and sense of place), provisioning (material benefits, such as commercial fish and shellfish harvest and ornamentals) and regulating (buffers to change, particularly coastal protection) services [6]. In contrast, "supporting ecosystem services" are not considered for analysis. These are intermediate services (e.g., nutrient recycling) that support the final ecosystem services evaluated in condition reports. Evaluating the benefits of both intermediate and final ecosystem services would result in double counting and thus an artificial inflation of benefits derived from resources within sanctuaries.

This paper focuses primarily on one provisioning ecosystem service-commercial harvest-and the economic impacts of proposed regulatory and marine zone changes. The commercial harvest ecosystem service is measured by the landings (in pounds) and the harvest revenue in this paper. However, one would be amiss to not acknowledge other ecosystem services provided by the sanctuary. Some include consumptive recreation (e.g., recreational fishing and collection of other resources), non-consumptive recreation (e.g., wildlife viewing, diving and snorkeling on reefs and shipwrecks), science, education, heritage, sense of place, subsistence harvest, ornamentals and coastal protection (via natural habitats such as mangroves and coral reefs). The analysis of impact to these other ecosystem services is provided in supporting documentation for the sanctuary's Restoration Blueprint and additional analysis to be provided as the proposed changes move through the regulatory process [7].

\subsection{Restoration Blueprint-Draft Environmental Impact Statement}

The sanctuary was established in 1990 by Congressional action and the final environmental impact statement, management plan and resulting regulations were completed in 1997. Sanctuaries are managed by regulations (which require environmental impact statements) and their respective management plans. Management plans for individual sanctuaries are prepared with considerable public involvement, and articulate visions, goals, objectives and priorities, summarize existing programs and regulations, and guide preparation of annual operating plans, management decision making, and planning of future projects [8]. 
The FKNMS management plan established the nation's first comprehensive network of marine zones based upon years of planning, design and public input. The marine zones offer varying levels of protection and allow different levels of use based on the goal of the marine zone. The establishment of marine zones in the sanctuary has resulted in many success stories of how responsible, informed management leads to conservation and restoration of resources. Success stories within FKNMS include improvements to black grouper, reef fish spawning grounds at Riley's Hump and a healthy seagrass meadow [2].

Despite the success stories, the existing regulations, marine zones and management plans of the mid-1990s are no longer sufficient to address the widespread, acute, chronic and emerging threats to marine resources. The FKNMS condition report published in 2011 found that most resources appeared to be in fair and fair/poor condition with a stable or declining trend [9]. Additionally, emerging threats to sanctuary resources include invasive species, climate change, increasing coastal and visitor populations and increasing recreational use. Further, since the condition report was released, the sanctuary has been impacted by Hurricane Irma (2017) [10], a coral disease outbreak (2016) [11], and a seagrass die-off (2015) [12].

Recognizing a need and urgency to address declining resource conditions and continued natural and anthropogenic threats, on April 19, 2012, NOAA and the US Department of Interior's (DOI) US Fish and Wildlife Service (USFWS) published a notice of intent to the Federal Register to conduct a marine zoning and regulatory review [13]. During 2012, hundreds of people participated in public meetings and submitted written comments to provide input on specific issues to be analyzed or addressed. Furthermore, the FKNMS Sanctuary Advisory Council (SAC) played a significant leadership role throughout the review process and in developing alternatives. (SACs are community-based advisory groups established to provide advice and recommendations to sanctuary leadership.)

The Draft Environmental Impact Statement (DEIS) for FKNMS was released in 2019. The DEIS presented four alternatives, including the status quo. It includes NOAA's proposal for the sanctuary boundary and sanctuary-wide regulations, and marine zone boundaries within the sanctuary and their regulations. NOAA received approximately 1200 separate comments during the public comment period and several letter campaigns and petitions, each with multiple signatories for a total of well over 32,000 comments. The types of organizations that commented include the following: state and federal agencies, local municipalities, homeowners associations, fishing organizations, diving organizations, non-governmental organizations, trade organizations, scientists, permit holders, and school groups.

This paper focuses primarily on scientific methods and economic analyses completed for commercial fishing, specific to marine zones (boundary and regulatory changes) to meet several regulatory mandates. There are five zone types proposed in the DEIS to protect shallow water habitats and dependent wildlife, reef structure, support research, and separate conflicting uses [2].

Since publishing the DEIS in 2019, FKNMS management has reviewed the public and agency comments, has consulted with partner agencies including from the state of Florida, NOAA National Marine Fisheries Service and the Gulf and South Atlantic Fishery Management Councils, and the U.S. Fish and Wildlife Service. NOAA's ONMS has used all of this input and additional scientific, socioeconomic, and use data to develop a single draft rule proposal. The draft rule proposal represents a combination of individual aspects of each of the four alternatives presented in the 2019 DEIS and is directly informed by the thousands of public and agency comments received on the DEIS. The draft rule will be released for a public comment opportunity in the fall/winter of 2021.

The analysis here will focus on the status quo, three alternatives presented in the 2019 DEIS and the proposed Draft Rule boundaries. Although it would not be appropriate to present maps of these alternative spatial zones here, the map below shows the current boundaries of FKNMS. 


\section{Analysis}

The analysis provided here considers fishing activity within the status quo, three boundary and marine zone alternatives included in the 2019 DEIS, and the draft rule proposal (four boundary alternatives in addition to the status quo). The exact spatial extent of the first three alternatives is available within the DEIS. The draft rule alternative analyzed here is still being considered for review and is expected to be finalized and released in fall/winter 2021. The areas where fishing is prohibited constitute a small fraction of the overall sanctuary, and spread throughout the region in small, targeted zones, of which 95\% are less than 5 square kilometers and 90\% are less than 1 square kilometer. Status quo, which provides the baseline of the existing level of activity, and all four alternatives are analyzed for their proposed impacts using the same method described here. The Figure 2 below shows the data used, the software used and the goal of the research.

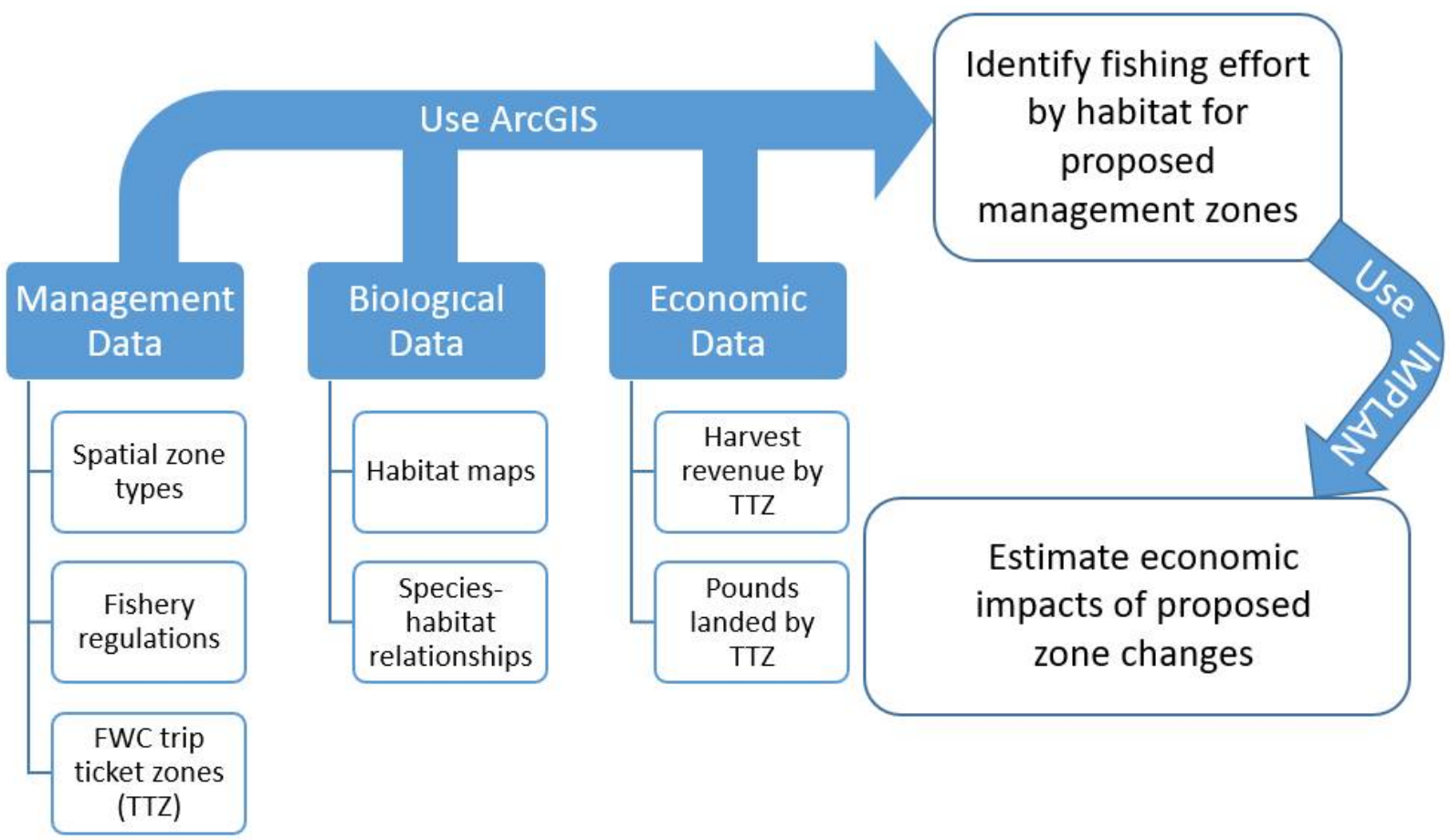

Figure 2. Analysis flowchart. A chart depicting the data used and software to achieve the impact estimates. All data come from secondary sources and is cited in this paper.

\subsection{Spatial Analysis: Biogeographic Assessment}

NOAA's National Centers for Coastal Ocean Science (NCCOS), in partnership with sanctuary staff, conducted a Biogeographic Assessment [14] of the Florida Coral Reef Tract. This effort collected and synthesized available information on the distribution of species, habitats, and additional ecosystem components into a consistent data framework to enable the spatial analysis of alternative management scenarios. This work incorporated information from a wide range of in situ surveys, remotely sensed data, and human use patterns.

FKNMS, through its Sanctuary Advisory Council, asked working groups of local stakeholders to recommend the locations, size, and shape of management units within the sanctuary, using both scientific knowledge and local knowledge. Each proposed management unit was first analyzed for representation of biological and ecological attributes, then assessed in a spatial prioritization exercise. This exercise enabled the establishment of a spatially and ecologically efficient set of areas, ultimately prioritized using human use and local knowledge considerations. The assessment incorporated existing knowledge of the distribution of coral and fish species, species assemblages, habitats, habitat use patterns, ecological context, human use patterns, and existing management structure. 


\subsection{Spatial Analysis: Using Habitat Maps}

NCCOS provided additional analysis of the sanctuary habitats, primarily ocean-side reef habitats, and associated use by selected fish species. They evaluated the potential change or loss of fishing access due to the proposed marine zone alternatives and directly informed the economic analysis described in Section 3.3. Information used in this analysis included the Unified Florida Reef Tract map [12], Florida fishery trip ticket zones maps and data on landings and harvest revenue that are collected by the state of Florida [15]. The analysis described in Section 3.2 utilizes ArcGIS Pro 2.8.0.

Landings and harvest revenues per species were averaged across five years (2015-2019) for each fishery trip ticket zones overlapping FKNMS. Species-habitat relationships for these nine species of reef-resident finfish and spiny lobster were derived from reef monitoring studies for five reef habitats: continuous high relief, continuous medium relief, continuous low relief, isolated high relief, isolated medium relief, isolated low relief, and rubble reef $[4,16]$. Habitat distributions were tracked using the Unified Florida Reef Tract Map developed by the Florida Fish and Wildlife Conservation Commission.

Ten reef species (nine fish and lobster) and two additional species (shrimp and stone $\mathrm{crab}$ ) were considered in this analysis. There were several reasons for the focus of the analysis on reef species. First, the spatial management zones being considered are concentrated in the reef tract, and consequently will primarily impact reef-based fishing and species. Secondly, the species-habitat relationships allowed for a spatially explicit estimation of effort based on where the fish are known to congregate. Third, many of these species are among the most valuable reef species when considering harvest revenue and each has a high per-unit value. Additionally, we considered shrimp and stone crab as high-value fisheries in the region, even though they are not reef obligate. While there are other high value species caught in sanctuary, they are not reef obligate and tend to be pelagic, with large habitat ranges and therefore were not included.

First, the landings (pounds and revenues) per species for each trip ticket zones were joined with the shapefile for Florida's fishery trip ticket zones. Subsets of a habitat map and fishery trip ticket zones were made to include only the relevant reef habitat types and any trip ticket zones that intersected the relevant habitat types. See Figure 3 for a map of these areas. Note that many of the bay-side trip ticket zones did not contain relevant reef habitat types.

Next, the gridded layer representing the seven reef habitat types was dissolved, so each habitat type was then a polygon rather than the original $100 \times 100$ grid. Using the union tool in ArcGIS, the habitat layer was then overlaid with the existing zones within the boundaries of FKNMS where fishing is prohibited and fishable habitat areas were exported in order to distribute fishing effort around all available habitat. This fishable habitat layer was intersected with commercial catch records by trip ticket zones for the commercial analysis. The proportions of fish in each habitat were multiplied by the landings information for each species for each trip ticket zones [4]. Three new fields were then calculated sequentially: catch per habitat (proportion of fish in each habitat multiplied by catch), area of each habitat area in each trip ticket zones, and fish per square meter (by multiplying the first two fields).

Two of the most important commercial fisheries-shrimp and stone crab-are not reef-associated and therefore could not be analyzed the same way as the commercial finfish species and lobster. Instead, commercial catch records were distributed uniformly across each associated Trip Ticket area for the Keys region, creating a shrimp and stone crab per square meter factor. 


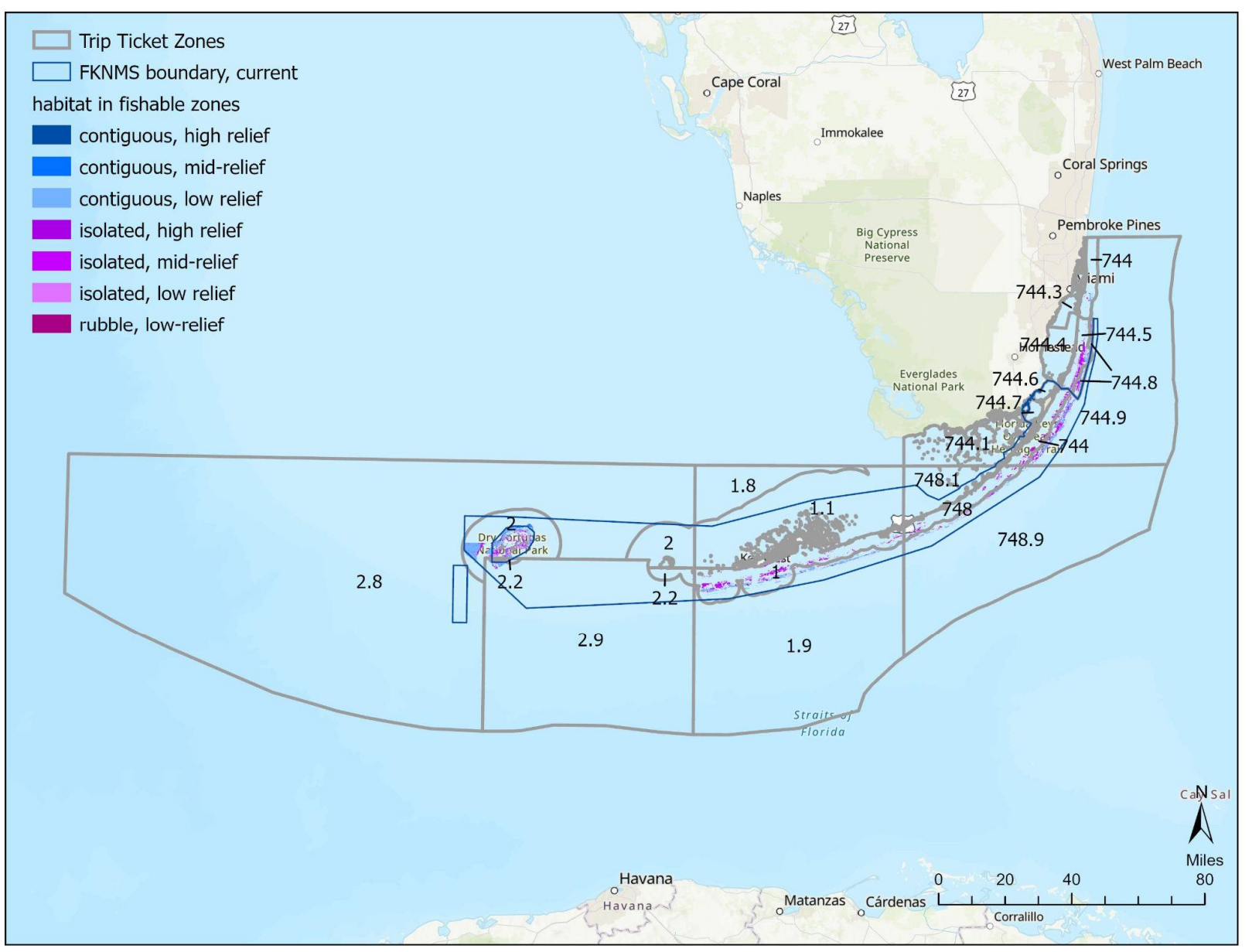

Figure 3. Trip ticket zones are layered over the outer boundary of the FKNMS and the reef tract habitat.

In order to analyze only changes in proposed areas, the shapefiles of each of the proposed alternatives were first filtered by whether fishing was allowed or prohibited, and then new layers were created representing the changes between the existing sanctuary marine zones and each proposed alternative suite of marine zones. This created two shapefiles for each alternative: areas added where fishing is prohibited, and areas where restrictions may be lifted, potentially allowing fishing where it is currently prohibited. These layers were intersected with the habitat/catch layers to create a series of layers showing habitat areas added in proposed marine zones, and areas and associated habitat removed from marine zones for each alternative. The area of each habitat in each of these layers was multiplied by fish per square meter to determine the potential catch lost: the final total was determined by subtracting values from the areas where fishing restrictions may be lifted from the proposed marine zone areas added for each alternative. Records for each species were maintained separately in the attribute table, so results are reported by species for each of the alternatives.

The baseline and potential maximum loss of activity for each species is presented in Table 1 below. The baseline presents the status quo level of activity. Alternatives 1, 2 and 3 are described in full detail within the Draft Environmental Impact Statement [2], and alternative 4 is the current proposed boundary to be presented in the FKNMS Draft Rule for release later this year. (Alternatives 2 and 3 propose the same spatial changes and are presented together in the table below.) The focus of this paper is on the proposed changes to different zone types and habitat areas within FKNMS. These proposed changes alter the uses within the boundaries of the zones. Value is based upon the unit price reported at the time of landing and the number of units landed. The value is related to the product as it was landed and sold. The landings are based upon the units landed from waters within 
Monroe County trip ticket zones. Generally speaking, landings (pounds) are presented by whole weight, with some exceptions [15]. Stone crabs are in claw weight, snappers and groupers are in gutted weight and spiny lobsters may be tailed. A conversion factor is used to produce the pounds of whole weight landed. Summary statistics are available on Florida's Fish and Wildlife Conservation Commission's (FWC) Commercial Fishing Landings website [17].

Table 1. Baseline value and pounds of landings from Monroe County waters and maximum potential loss by alternative (monetary estimates in 2019 dollars).

\begin{tabular}{|c|c|c|c|c|}
\hline Species & $\begin{array}{c}\text { Baseline Status Quo } \\
\text { Activity }\end{array}$ & $\begin{array}{l}\text { Alternatives } 2 \text { and } 3 \\
\text { Net Change }\end{array}$ & $\begin{array}{c}\text { Alternative } 4 \text { Net } \\
\text { Change }\end{array}$ & $\begin{array}{c}\text { Proposed Rule Net } \\
\text { Change }\end{array}$ \\
\hline Black grouper revenue & $\$ 403,367$ & $-\$ 90$ & $-\$ 13,443$ & $-\$ 1343$ \\
\hline Black grouper pounds & 84,539 & -19 & -2711 & -283 \\
\hline Red grouper revenue & $\$ 1,659,793$ & $-\$ 13$ & $-\$ 21,772$ & $-\$ 389$ \\
\hline Red grouper pounds & 445,373 & -3 & -5837 & -96 \\
\hline Grunts revenue & 14,905 & $-\$ 7$ & $-\$ 722$ & $-\$ 53$ \\
\hline Grunts pounds & 12,028 & -5 & -665 & -41 \\
\hline Hogfish revenue & $\$ 44,128$ & $-\$ 41$ & $-\$ 1389$ & $\$ 305$ \\
\hline Hogfish pounds & 9800 & -9 & -320 & -70 \\
\hline Gray snapper revenue & $\$ 302,068$ & $-\$ 21$ & $-\$ 21,660$ & $-\$ 726$ \\
\hline Gray snapper pounds & 110,552 & -7 & -8806 & -259 \\
\hline Lane snapper revenue & $\$ 19,086$ & $\$ 0$ & $-\$ 891$ & $-\$ 22$ \\
\hline Lane snapper pounds & 7215 & 0 & -472 & -10 \\
\hline Mutton snapper revenue & $\$ 337,168$ & $-\$ 129$ & $-\$ 13,270$ & $-\$ 1539$ \\
\hline Mutton snapper pounds & 109,547 & -36 & -4368 & -435 \\
\hline Yellowtail snapper revenue & $\$ 7,432,618$ & $-\$ 1149$ & $-\$ 877,682$ & $-\$ 16,839$ \\
\hline Yellowtail snapper pounds & $2,289,397$ & -345 & $-256,187$ & -5221 \\
\hline Lobster revenue & $\$ 42,004,990$ & $-\$ 1802$ & $-\$ 955,666$ & $-\$ 965,833$ \\
\hline Lobster pounds & $5,023,736$ & -207 & $-102,200$ & $-115,236$ \\
\hline Gag grouper revenue & $\$ 145,776$ & $-\$ 3$ & $-\$ 2922$ & $-\$ 53$ \\
\hline Gag grouper pounds & 30,800 & -1 & -615 & -11 \\
\hline Stone crab revenue & $\$ 20,159,926$ & $-\$ 13,728$ & $\$ 118,735$ & $-\$ 37,714$ \\
\hline Stone crab pounds & $1,443,427$ & -931 & -8356 & -2564 \\
\hline Shrimp revenue & $\$ 20,884,677$ & $\$ 42$ & $-\$ 9467$ & $\$ 5$ \\
\hline Shrimp pounds & $8,951,302$ & 18 & -3999 & 2 \\
\hline
\end{tabular}

\subsection{Economic Analysis}

Building from the biogeographic and spatial analysis, the economic analysis seeks to estimate the maximum potential loss. Maximum potential loss is a conservative measure that assumes all activity within a spatial zone would be lost. For example, if a spatial zone is closed to commercial fishing (or a specific gear type), the assumption is that all the activity would be lost and that there would be no substitution to other places (or other gear types). The existing spatial zones range in size, from 109 square miles in the Tortugas Ecological Reserve North to 0.07 square miles in the Cheeca Rocks Sanctuary Preservation Area. The proposed zones in the Draft Rule range in size from 259 square miles to 0.01 square miles, and the fact that activity would still be allowed outside the zones, it is unlikely that the 
maximum potential loss would occur. Nevertheless, this is the analytical upper bound and required for regulatory analysis.

Data for the economic analysis were provided by the FWC. The data include the year of the fishing activity, the trip ticket zones area and its written description, the species name, units (the weight of the product based upon how it is landed-whole, gutted, tails, heads-on, heads-off, etc.), and the unit price based upon how the species was landed and conversion units. Although the trip identification remained the same, the dealer, fisher, commercial fishing license and vessel identification were all replaced with a unique sequential number for each dealer, fisher, license and vessel throughout the database before providing the information to NOAA. This protected the privacy of individual dealers, fishers and license holders.

The analysis here considers the five-year annual average activity from the period 2015-2019 of harvest revenue and landings by species. Using the average annual level of activity mitigates the effect of extremes in the data (such as Hurricane Irma and other extreme weather or ecological events). The primary variables used to determine impacts are harvest revenue and pounds landed. Harvest revenue only considers fish that were landed and sold. In some cases, fish may be caught, but not sold due to defects, lack of demand or by-catch that is not sellable. It would not be appropriate to consider these non-purchases $(0.61 \%$ of all observations) in the analysis, as they do not contribute to revenue. The results presented here are not a cost-benefit analysis, nor a substitute for one, but rather focus on changes in the distribution of economic activity in the region.

Following the analysis of impacts to the landings and their value, the economic impact of the resulting spatial changes were estimated. For the status quo, the current level of economic activity supported by commercial harvest for the selected species was estimated. The national and coastal state input/output $(\mathrm{I} / \mathrm{O})$ model was used to estimate the impacts associated with fish harvesting (including finfish and shellfish) by U.S. commercial fishermen and the activities of industries (seafood and retail) dependent upon those fish [18]. (Input/output modeling allows for the estimation of economic impacts to a local, regional or national economy. The model uses quantitative data that represent the interdependencies between different sectors of the economy.) The estimation of impacts follows the fish as they move through the U.S. and state of Florida supply chains, ending with the final sale to consumers in, or export from, the respective area of interest (U.S. or Florida).

Impacts are expressed in terms of total jobs (full-time and part-time jobs combined), income, total value-added (contribution to gross domestic product) and output (sales) in either the U.S. or state of Florida [18]. The scope of the impacts reflects commercial fish harvesting in U.S. waters off Monroe County and includes commercial fishing related activities, such as by processors, wholesalers/distributors, retail grocers, and restaurants. Additionally, the impacts included in Tables 2 and 3 are inclusive of direct, indirect and induced impacts. The model is capable of estimating impacts for the entire country and 23 marine coastal states. The results presented here measure the existing level of economic activity and resulting impacts to the U.S. (Table 2) and Florida (Table 3) for fish landed from the FWC trip ticket zones surrounding Monroe County (status quo) and the four spatial alternatives, respectively. The U.S. multipliers in the I/O model are greater than the state multipliers, because they account for interstate and interregional trading; whereas, the state multipliers do not.

Baseline activity and impacts were estimated for the species of interest along with expected changes from each alternative. The I/O model used was developed for the analysis of eighteen distinct species groupings including shrimp, crab, lobster and reef fish [18]. The species identified in Table 1 were grouped accordingly as inputs to the model. The results are summarized in Tables 2 and 3 below for U.S. and Florida activity, respectively. The numbers reflect average annual landings value from 2015 to 2019 and are shown in 2019 dollars for the species analyzed. (Harvester jobs are identified separately even though they are also included within the total jobs). 
Table 2. Average annual U.S. business activity (2015-2019) associated with the commercial sale of finfish and shellfish harvested from trip ticket zones around Monroe County with the expected change from spatial alternatives in 2019 dollars.

\begin{tabular}{|c|c|c|c|c|c|c|}
\hline Alternative & $\begin{array}{c}\text { Average Ex-Vessel } \\
\text { Value } \\
\text { (\$ Thousands) }\end{array}$ & Total Jobs & $\begin{array}{l}\text { Harvester } \\
\text { Jobs }\end{array}$ & $\begin{array}{l}\text { Output (Sales) } \\
\text { Impacts } \\
\text { (\$ Thousands) }\end{array}$ & $\begin{array}{c}\text { Income } \\
\text { Impacts } \\
\text { (\$ Thousands) }\end{array}$ & $\begin{array}{l}\text { Value Added } \\
\text { (\$ Thousands) }\end{array}$ \\
\hline $\begin{array}{l}\text { No action } \\
\text { (baseline) }\end{array}$ & $\$ 93,409$ & 1722 & 2752 & $\$ 921,761$ & $\$ 337,934$ & $\$ 478,379$ \\
\hline $\begin{array}{c}\text { Alternative } 2 \text { net } \\
\text { change }\end{array}$ & $-\$ 17$ & -2 & -1 & $-\$ 168$ & $-\$ 62$ & $-\$ 88$ \\
\hline $\begin{array}{c}\text { Alternative } 3 \text { net } \\
\text { change }\end{array}$ & $-\$ 17$ & -2 & -1 & $-\$ 168$ & $-\$ 62$ & $-\$ 88$ \\
\hline $\begin{array}{c}\text { Alternative } 4 \text { net } \\
\text { change }\end{array}$ & $-\$ 2038$ & -258 & -62 & $-\$ 20,210$ & $-\$ 7463$ & $-\$ 10,536$ \\
\hline $\begin{array}{c}\text { Proposed rule net } \\
\text { change }\end{array}$ & $-\$ 1025$ & -130 & -32 & $-\$ 10,168$ & $-\$ 3773$ & $-\$ 5324$ \\
\hline
\end{tabular}

Table 3. Average annual Florida business activity (2015-2019) associated with the commercial sale of finfish and shellfish harvested from trip ticket zones around Monroe County with the expected change from spatial alternatives in 2019 dollars.

\begin{tabular}{|c|c|c|c|c|c|c|}
\hline Alternative & $\begin{array}{c}\text { Average Ex-Vessel } \\
\text { Value } \\
\text { (\$ Thousands) }\end{array}$ & Total Jobs & $\begin{array}{c}\text { Harvester } \\
\text { Jobs }\end{array}$ & $\begin{array}{l}\text { Output (Sales) } \\
\text { Impacts } \\
\text { (\$ Thousands) }\end{array}$ & $\begin{array}{c}\text { Income } \\
\text { Impacts } \\
\text { (\$ Thousands) }\end{array}$ & $\begin{array}{l}\text { Value Added } \\
\text { (\$ Thousands) }\end{array}$ \\
\hline $\begin{array}{l}\text { No action } \\
\text { (baseline) }\end{array}$ & $\$ 93,409$ & 3741 & 2423 & $\$ 385,429$ & $\$ 101,683$ & $\$ 156,200$ \\
\hline $\begin{array}{c}\text { Alternative } 2 \text { net } \\
\text { change }\end{array}$ & $-\$ 17$ & -1 & 0 & $-\$ 68$ & $-\$ 19$ & $-\$ 28$ \\
\hline $\begin{array}{c}\text { Alternative } 3 \text { net } \\
\text { change }\end{array}$ & $-\$ 17$ & -1 & 0 & $-\$ 68$ & $-\$ 19$ & $-\$ 28$ \\
\hline $\begin{array}{c}\text { Alternative } 4 \text { net } \\
\text { change }\end{array}$ & $-\$ 2038$ & -84 & -56 & $-\$ 8215$ & $-\$ 2251$ & $-\$ 3405$ \\
\hline $\begin{array}{c}\text { Proposed rule net } \\
\text { change }\end{array}$ & $-\$ 1025$ & -42 & -28 & $-\$ 4130$ & $-\$ 1133$ & $-\$ 1713$ \\
\hline
\end{tabular}

\subsection{Findings}

As expected, the impacts to the U.S. are larger than the impacts to the state of Florida. Alternatives 2 and 3 have the smallest estimated impacts, followed by the draft rule, and finally alternative 4 . Focusing on the impacts to Florida, the proposed draft rule may result in an estimated loss of 42 jobs, with 28 being harvester jobs. Further, it is estimated that $\$ 4.1$ million in output will be lost and approximately $\$ 1.1$ million in income.

The impacts presented in Tables 2 and 3 are the maximum potential loss and do not allow for substitution of current fishing areas for other similar and compatible resources. Each spatial zone proposed to be added to the existing suite of marine zones is relatively small ( $95 \%$ are less than 5 square kilometers and $90 \%$ are less than 1 square kilometer) and it is likely that commercial harvesters will (over time) find replacement areas and/or benefit from spillover from improvements to reefs and fish communities within closed areas. Further, the economic impacts presented assumes upstream producers and consumers would not substitute other goods (e.g., other domestic fish, imports or other types of food products) and services (e.g., food service at other restaurants) for those species affected by the action, when it is very likely they would. The model also assumes inputs other than fish 
used in the production process would not be re-employed elsewhere to generate similar economic activity.

Studies in California showed very little to no negative impacts in a marine reserve network established there [19]. The five-year review found that four of the seven species/species groups did not see the estimated maximum potential loss of revenues (rock crab, spiny lobster, squid and sea urchin). Sea cucumbers did experience a loss, but this was less than projected and less than the statewide decrease experienced over the same time period. CA sheephead and rockfish experienced losses greater than projected estimates and the observed statewide declines, but only accounted for $0.85 \%$ and $0.84 \%$, respectively, of total harvest value prior to the implementation of the marine reserve network.

In the ten-year analysis [19], the harvest value of urchin, spiny lobster, crab, rockfish, sea cucumbers, CA sheepshead and prawn and shrimp experienced increases. Rockfish and wet fish experienced declines in harvest value. When considering the total value of all commercial fisheries, the value increased pre to post implementation of the marine reserve network. Although there was a decline in the number of fishing operations, the revenue per fishing operation increased from approximately $\$ 48$ thousand to $\$ 110$ thousand pre to post implementation. The findings suggest that predicted negative impacts did not occur and instead a gain was possible.

A study completed in 2012 analyzed the impacts to commercial fisheries of the creation of a no-take area for the Tortugas Ecological Reserve (TER) from 1997 to 2006 [20]. The no-take reserves were created in 2001 by state and federal agencies within FKNMS. The researchers found that the spatial distribution of SPL holders that fished in the Tortugas increased their proportion of revenues derived in the Tortugas region, accompanied by a decrease in fishing revenues from other areas in Key West and Florida. This finding supports the idea that even in the event of displacement from specific fishing areas, spatial substitution by fishermen will occur. The same study also found that total ex-vessel revenues from all catch in the Tortugas area declined from pre to post TER. Most of the decline was due to the price of shrimp decreasing ( $\$ 4.30$ per pound pre-TER to $\$ 2.36$ per pound post TER), which accounted for, on average, $67 \%$ of total ex-vessel revenue pre-Ter and $55 \%$ in the post TER period. Despite the decrease in revenues, total pounds of shrimp catch increased between the pre and post periods. Declines in revenue were also seen in the spiny lobster fishery, but increased revenues were observed for reef fish, King Mackerel, stone crabs and all other species. When excluding the loss of revenues due to the shrimp fishery, an overall increase in ex-vessel revenues from catch in the Tortugas occurred post TER.

More recently, a study examining the economic impacts of the 2016 expansion of Papahānaumokuākea Marine National Monument (PMNM) estimated that catch per unit effort dropped by $7 \%$ and revenue dropped by $9 \%$ per trip in the first 16 months of the post-expansion period [21]. However, the author stated that the reason for the negative impacts was that those who fished inside the expanded area are still becoming more proficient in finding areas with comparable productivity. Further, although this study found short term losses, the expansion of the monument was much different than the proposed zone changes in FKNMS. The monument expanded from 139,793 to 582,578 square miles of waters and submerged lands in the Northwestern Hawaiian Islands. The changes proposed in FKNMS are more comparable to those in California, where small, non-contiguous areas were designated for increased protection. In the California analysis, impacts were negligible.

\section{Conclusions}

\subsection{Adaptability to Other Sites and Limitations}

The Florida Keys reef tract, especially in the sanctuary, is a region of high research attention and therefore has high data availability across many concepts. The data used here rely on spatially explicit commercial fishing tracking, which has expanded across the United States within the last 10-15 years. It also relies on the application of the Unified Florida 
Reef Tract Map, which is an integrated product developed from multiple independent mapping efforts [16].

Finally, the spatial analysis relies on a detailed understanding of the relationship between those closely tracked fishery species and the Unified Reef Tract Map. For the Florida Keys, both the habitat map and the fish-habitat relationship data are made possible by a multi-institution collaboration that sent divers to different types of habitats to count the number of fish found in each habitat type [4]. This type of study is labor intensive and costly, and therefore not available in many places. Even for the Florida Keys, these fish-habitat relationships (a key step in the spatial analysis calculations) were measured more than a decade ago and only in the Tortugas, the westernmost portion of Florida Keys National Marine Sanctuary. If the spatial economic methodology presented here is to be used for long-term monitoring in the Keys or deployed in other locations, this type of study should be updated.

A significant amount of additional data have been collected and analyzed in association with this project. Additional work was completed to support the analysis, but not presented here. This included a geodatabase of the information synthesis of biological, ecological, and human use patterns. A MARXAN analysis to identify highest priority areas for ecosystem management, and a gap analysis to determine the biological and ecological representation of each proposed management scenario.

\subsection{What This Analysis Does Not Include}

This analysis does not include the expected impacts to other user groups, such as recreational fishers, divers and other non-consumptive users or for-hire charter operations and tour guides in the region. Other ecosystem services provided by the site, not evaluated here, include education, shoreline protection and science. This analysis does not provide a cost-benefit analysis and consequently does not consider non-market values from loss of activity or gains in resource protection and condition. A study conducted in 2001 surveyed users of coral reefs and estimated that the willingness to pay for protection of artificial and natural reefs was $\$ 25.52$ per person-per day (in 2019\$) and aggregating this across all reef users resulted in a total value of $\$ 6.17$ million dollars [22]. There are no recent studies estimating the willingness to pay for various user groups for improvements to reef conditions in FKNMS or Monroe County.

Further, the commercial fishing analysis was restricted to primarily reef-associated species. It is likely that other commercial harvesters that target non-reef fish may also be negatively affected by these proposed spatial zone changes, albeit to a lesser extent. However, this analysis focused on the most likely species to be impacted that had some of the highest commercial value of the 2015-2019 study period.

\subsection{Future Work}

The Florida Keys reef tract is a dynamic ecosystem, and increasingly so under the pressures of climate change. Warmer water temperatures have led to massive outbreaks of stony coral tissue loss disease, which in turn has drastically decreased both coral biodiversity and live coral cover in the last 5 years [23]. Warmer water temperatures have also increased the number and intensity of hurricanes in the region as a whole, and these hurricanes also change the coral community structure and distribution through ecological changes and direct structural damage, as evidenced in the aftermath of Hurricane Irma in 2017 [24]. Therefore, habitat maps and fish-habitat relationships should be measured repeatedly through long-term monitoring and updated after major community-altering natural disasters. This study used current commercial catch records but outdated Unified Reef Map and fish-habitat relationships because they are the best, most recently available.

Future work should include a replication of this study to determine if the maximum potential loss estimates were realized. As mentioned above, many studies find that maximum potential losses are not fully realized in the long run as operations have time to adopt or find suitable substitute locations. This may require working with the commercial 
fisherman expected to be impacted by these rule changes in addition to analyzing the level of commercial fishing in the future within the trip ticket zones around Monroe County.

Further, expanding the analysis to consider the impacts of the proposed changes to the recreational fishing industry, the dive and snorkeling industry and other ecosystem services is planned and will be published later this year. Additionally, conducting a stated-preference study to provide updates to the willingness to pay for both users and nonusers for resource condition improvements should be considered. Long-term, continued ecosystem and ecosystem service studies will help to determine the efficacy and level of success of the proposed management changes to protect and conserve the Florida Keys and the unique habitats that compose FKNMS.

Author Contributions: Conceptualization, D.S., A.F., and D.D.; methodology, D.S., A.F., D.D., and D.R.; formal analysis, D.S., A.F., D.D., and D.R.; writing-original draft preparation, D.S., A.F., D.D., and M.W.; writing-review and editing, D.S., A.F., D.D., and D.R.; supervision, D.S. All authors have read and agreed to the published version of the manuscript.

Funding: This research was funded by the existing budget of NOAA and did not receive external grant funding.

Data Availability Statement: Please contact the authors for specific information about the data used. Certain data are confidential and require data sharing agreements.

Acknowledgments: The authors would like to thank staff at NOAA's Office of National Marine Sanctuaries, National Center for Coastal and Ocean Science and Southeast Fisheries Science Center and Florida Keys National Marine Sanctuary for their helpful support of this research project. Thanks also to Angela Orthmeyer and Bob Leeworthy for initiating this project and beginning to develop the methodology. The authors would also like to thank Beth Dieveney, Steve Gittings and Ed Lindelof for their review and edits of this manuscript.

Conflicts of Interest: The authors declare no conflict of interest.

\section{References}

1. National Marine Sanctuaries About. Available online: https:/ / sanctuaries.noaa.gov/about/ (accessed on 14 June 2021).

2. Office of National Marine Sanctuaries. Draft Environmental Impact Statement for Florida Keys National Marine Sanctuary: A Restoration Blueprint; U.S. Department of Commerce, National Oceanic and Atmospheric Administration, Office of National Marine Sanctuaries: Silver Spring, MD, USA, 2019; p. 550.

3. How Important Is Tourism to the Florida Keys \& Key West. Available online: https://www.monroecounty-fl.gov/ DocumentCenter/View/23136/Toursim-Fact-Sheet-?bidId= (accessed on 14 June 2021).

4. Smith, S.G.; Ault, J.S.; Bohnsack, J.A.; Harper, D.E.; Luo, J.; McClellan, D.B. Multispecies survey design for assessing reef-fish stocks, spatially explicit management performance, and ecosystem condition. Fish. Res. 2011, 109, 25-41. [CrossRef]

5. Burke, J.; Judson Kenworthy, W.; Shay Viehman, T.; McDonough, V.; Degan, B. Biodiversity and Ecosystem Function of Shallow Bank Systems within Florida Keys National Marine Sanctuary (FKNMS. Marine Sanctuaries Conservation Series ONMS-12-03; U.S. Department of Commerce, National Oceanic and Atmospheric Administration, Office of National Marine Sanctuaries: Silver Spring, MD, USA, 2011; p. 45.

6. Description of Ecosystem Services and Methods to Determine Ratings. Available online: https://sanctuaries.noaa.gov/science/ condition/ecosystem.html (accessed on 26 June 2021).

7. Leeworthy, V.; Schwarzmann, D.; Shea, R. Florida Keys National Marine Sanctuary: Supporting Analysis for the Restoration BlueprintConservation Science Series ONMS 19 06; U.S. Department of Commerce, National Oceanic and Atmospheric Administration, Office of National Marine Sanctuaries: Silver Spring, MD, USA, 2019; p. 228.

8. Management 101. Available online: https://sanctuaries.noaa.gov/management/mgt101.html (accessed on 14 June 2021).

9. Office of National Marine Sanctuaries. Florida Keys National Marine Sanctuary Condition Report; U.S. Department of Commerce, National Oceanic and Atmospheric Administration, Office of National Marine Sanctuaries: Silver Spring, MD, USA, $2011 ;$ p. 105.

10. Post-Hurricane Irma images. Available online: https:/ floridakeys.noaa.gov/whatsnew / releases/2017/post-hurricane-irmagallery.html (accessed on 27 September 2021).

11. Florida's Coral Reef Disease Outbreak. Available online: https://floridakeys.noaa.gov/coral-disease/ (accessed on 27 September 2021).

12. Yarbro, L.A.; Carlson, P., Jr. Executive summary. In Seagrass Integrated Mapping and Monitoring Report No. 2. Fish and Wildife Research Institute Technical Report TR-17, Version 2; Yarbro, L.A., Carlson, P.R., Jr., Eds.; Florida Fish and Wildlife Conservation Commission: St. Petersburg, FL, USA, 2016; pp. 1-28, 281. [CrossRef] 
13. Revisions of Boundaries, Regulations and Zoning Scheme for Florida Keys National Marine Sanctuary; Revisions of Fish and Wildlife Service and State of Florida Management Agreement for Submerged Lands Within Boundaries of the Key West and Great White Heron National Wildlife Refuges and Regulations; Intent to Prepare a Draft Environmental Assessment or Environmental Impact Statement; Notice of Scoping Meetings. Available online: https:/ /www.federalregister.gov/documents/2012/04/19/2 012-9345/revisions-of-boundaries-regulations-and-zoning-scheme-for-florida-keys-national-marine-sanctuary (accessed on 14 June 2021).

14. Caldow, C.; Monaco, M.; Pittman, S.; Kendall, M.; Goedeke, T.; Menza, C.; Kinlan, B.; Costa, B. Biogeographic assessments: A framework for information synthesis in marine spatial planning. Mar. Policy 2015, 51, 423-432. [CrossRef]

15. Commercial Fisheries Landing in Florida. Available online: https://myfwc.com/research/saltwater/fishstats/commercialfisheries/landings-in-florida/ (accessed on 27 June 2021).

16. Brandt, M.E.; Zurcher, N.; Acosta, A.; Ault, J.S.; Bohnsack, J.A.; Feeley, M.W.; Harper, D.E.; Hunt, J.H.; Kellison, G.T.; McClellan, D.B.; et al. A Cooperative Multi-Agency Reef Fish Monitoring Protocol for the Florida Keys Coral Reef Ecosystem NPS/SFCN/NRR2009/150; U.S. Department of Interior, National Park Service, Natural Resource Program Center: Fort Collins, CO, USA, 2009; p. 110.

17. Commercial Fisheries Landings Summaries. Available online: https://public.myfwc.com/FWRI/PFDM/ReportCreator.aspx (accessed on 14 June 2021).

18. National Marine Fisheries Service. A User's Guide to the National and Coastal State I/O Model; Department of Commerce, National Fisheries Service: Silver Spring, MD, USA, 2011; p. 39.

19. California Department of Fish and Wildlife. The First Five Years of Monitoring the Channel Islands Marine Protected Area NetworkFebruary 7-8, 2008; State of California, California Department of Fish and Wildlife: Sacramento, CA, USA, 2008. Available online: https:/ / www.wildlife.ca.gov/Conservation/Marine/MPAs/Planning-Process-HistoricalInformation/Channel-IslandsMPAs-Monitoring (accessed on 20 May 2021).

20. Jeffrey, C.F.G.; Leeworthy, V.R.; Monaco, M.E.; Piniak, G.; Fonseca, M. (Eds.) An Integrated Biogeographic Assessment of Reef Fish Populations and Fisheries in Dry Tortugas: Effects of No-take Reserves. NOAA Technical Memorandum NOS NCCOS 111; Department of Commerce, National Oceanic and Atmospheric Administration, National Center for Coastal and Ocean Science, Center for Coastal Monitoring and Assessment Biogeography Branch: Silver Spring, MD, USA, 2012; p. 147. Available online: http:/ / sanctuaries.noaa. gov/science/socioeconomic/floridakeys/pdfs/tortugasassessmentreport_final.pdf (accessed on 14 June 2021).

21. Chan, H.L. Economic impacts of Papahānaumokuākea Marine National Monument expansion on the Hawaii longline fishery. Mar Policy 2020, 115, 103869. Available online: https:/ / www.sciencedirect.com/science/article/pii/S0308597X19300090 (accessed on 1 June 2021). [CrossRef]

22. Johns, G.M.; Leeworthy, V.R.; Bell, F.; Bonn, M.A. Socioeconomic Study of Reefs in Southeast Florida: South Florida; State of Florida, Florida Fish and Wildlife Conservation Commission \& Department of Commerce, National Oceanic and Atmospheric Administration: Silver Spring, MD, USA, 2001.

23. Florida's Coral Reef Disease Outbreak. Available online: https://mote.org/research/program/coral-health-and-disease/floridacoral-disease-outbreak (accessed on 1 August 2021).

24. Post-Hurricane Irma Images. Available online: https:/ /www.usgs.gov/media/galleries/hurricane-irma-pre-and-post-stormphoto-comparisons-florida-keys (accessed on 1 August 2021). 